\title{
WOJSKO W ZMAGANIACH Z NATURA W ŚWIETLE KRONIK ANONIMA TZW. GALLA I MISTRZA WINCENTEGO ZWANEGO KADŁUBKIEM
}

\section{W}

pływ czynników naturalnych na prowadzenie działań wojennych na przestrzeni dziejów nierzadko decydował o losach poszczególnych kampanii. Elementy środowiska naturalnego już same w sobie stwarzały dogodne warunki do obrony konkretnego punktu oporu lub zaskoczenia przeciwnika ${ }^{1}$. Trzeba jednak podkreślić, że bez dobrze zorganizowanej obrony nie przedstawiały większej wartości, np. rola kompleksów leśnych nie była jednoznaczna, jeśli wziąć pod uwagę prowadzenie wojen lub nawet mniejszych potyczek. Utrudniały one wprawdzie marsz przeciwnikowi, ale pozwalały dodatkowo niepostrzeżenie podejść do celu wyprawy, a nawet skutecznie wycofać się po akcji. Wymowny jest fakt, że zalesienie Polski średniowiecznej było bardzo duże, gdyż sięgało do 50-60\% jej powierzchni. Zwarte kompleksy leśne, głównie iglaste (sosna, świerk), występowały na obszarze pogranicza z Prusami oraz na Pomorzu aż po Odrę. Z kolei w Karpatach i Sudetach lasy były bardziej rozmaite, tylko w wyższych partiach z przewagą świerka². Celowo podkreślamy ten fakt, gdyż wspomniane tereny były częstym teatrem wojny pojawiającym się na kartach interesujących nas źródeł pisanych.

Celem niniejszego artykułu jest w związku z tym prześledzenie zmagań wojsk z naturą w czasie marszu i podczas konkretnych działań zbrojnych z uwzględnieniem jej wpływu na powodzenie/niepowodzenie potyczek na podstawie relacji

${ }^{1}$ Rolę środowiska geograficznego omawia K. OlejnıK, Obrona polskiej granicy zachodniej. Okres rozbicia dzielnicowego i monarchii stanowej (1138-1385), Poznań 1970, s. 23 i n.

${ }^{2}$ J. Tyszkiewicz, Ludzie i przyroda w Polsce średniowiecznej, Warszawa 1983, s. 25. 
kronikarzy wymienionych w tytule, a także uchwycenie kontekstów (interesować nas będą tylko aspekty militarne), w jakich pojawiają się poszczególne komponenty krajobrazu naturalnego. Występują one w różnych ujęciach kronikarskich, co zostanie ukazane przede wszystkim w odniesieniu do słabiej opracowanych lub całkowicie pomijanych dotychczas wątków.

Pierwszą interesującą nas wzmianką jest fragment z kroniki Anonima tzw. Galla, dotyczący zmagań Bolesława Szczodrego z Czechami, którzy z całą armią wkroczyli do Polski, przemierzając leśne gąszcze [wyróżnienie - Ł.Ć.], co zapewne uczynili ze sporą łatwością, skoro zaskoczyli polskiego władcę. Ciekawie brzmią natomiast słowa samego zainteresowanego, który za pośrednictwem swych posłów miał zarzucać najeźdźcom, że ci działają podstępnie i znikają w kryjówkach leśnych ${ }^{3}$. Bolesław musiał zmagać się ponadto z Pomorzanami, którzy znienacka wdarli się na terytorium Polski. Na wieść o tym władca

pragnąc wszakże gorąco oswobodzić kraj z rąk niewiernych, zanim jeszcze wojsko się zebrało, musiał wyprzedzając je maszerować nazbyt nieostrożnie. Gdy przybyto nad rzekę, poza którą obozowały gromady pogan, rycerstwo obarczone orężem i kolczugami, nie szukając mostu ani brodu, rzucało się w jej głębokie nurty. I wielu pancernych poginęło tam przez własne zuchwalstwo, a pozostali zrzucili z siebie kolczugi i przepłynąwszy rzekę [wyróżnienie - Ł.Ć.], odnieśli zwycięstwo, aczkolwiek okupione stratami ${ }^{4}$.

Kończąc tę relację, kronikarz stwierdził, że od tej pory Polacy odzwyczaili się od noszenia pancerzy i nacierali na wroga swobodniej oraz bezpieczniej pokonywali rzekę bez wspomnianych kolczug ${ }^{5}$. Z powyższego fragmentu ewidentnie przebija lekkomyślność wojska, które chcąc za wszelką cenę dopaść przeciwnika, zginęło niepotrzebnie w nurtach rzeki. Warto przy tej okazji wspomnieć, że epizod ten został odnotowany w żywocie mniejszym św. Stanisława, w którym to główną przyczyną klęski rycerzy był nie tyle pancerz, co raczej ogólnie zbroje

3 Anonim tzw. Gall, Kronika polska, tłum. R. Grodecki, wstęp i oprac. M. Plezia, Wrocław 2003 [dalej: GAll], s. 49; Galli Anonymi Cronicae et gesta ducum sive principum Polonorum, wyd. K. Maleczyński, [w:] Monumenta Poloniae Historica [dalej: MPH], s.n., t. II, Kraków 1952 [dalej: Gall MPH], s. 49.

4 Gall, s. 50; Gall MPH, s. 50: „Qui cupiens animo ferventi de manu gentilium patriam liberare, collecto nondum exercitu decrevit antecedens inconsulte nimium properare. Cumque ventum esset ad fluvium, ultra quem turme gentilium residebant, non ponti requisite vel vado loricati milites et armati sed profundo gurgiti se credebant. Pluribus itaque loricatorum ibi presumptuose submerses, loricas reliqui superstites abiecerunt, transmeatoque flumine, quamvis dampnose victoriam habuerunt".

5 Gall, s. 50; Gall MPH, s. 50. Szerzej zagadnienie przekraczania rzek przez wojska analizuje T. GrabarczyK, „Sucha stopa” czy „skaczac w fale”. Przekraczanie rzek przez wojska polskie od XI do poczatku XVI wieku, „Acta Universitatis Lodziensis. Folia Historica” 2017, t. XCIX, s. 83-109. 
lub szeroko rozumiane uzbrojenie $(\mathrm{arma})^{6}$. W kronice Mistrza Wincentego zwanego Kadłubkiem również znajdujemy opis tych wydarzeń. Według niego

wielu tedy [nadmiernie] obciążonych zbroją zalewają fale. Wynurza się [tylko] garstka [rycerzy] wraz z królem i chociaż bezbronni odnoszą oni chlubne zwycięstwo nad mnogością uzbrojonych wrogów ${ }^{7}$.

Najwięcej miejsca na kartach swojej kroniki poświęcił Gall - co oczywiste - Bolesławowi Krzywoustemu. W kontekście podjętej tematyki warto powołać się na fragment, zgodnie z którym książę, przebywający wówczas w Rudzie, udał się z niewielkim orszakiem na łowy. Niestety, myśliwi natknęli się na Pomorzan ukrytych w gąszczu leśnym [wyróżnienie - Ł.Ć.] i natychmiast stoczyli z nimi walkę. Według Galla, siły księcia liczyły 80 spośród chłopców i młodzieńców, siły pogan były zaś zdecydowanie większe, albowiem zostały oszacowane przez dziejopisarza na 3000 wojowników. Dodajmy tylko, że Bolesław kontynuował walkę z 30 towarzyszami broni, a zatem musiał stracić znaczną część swych oddziałów ${ }^{8}$. Nie ulega natomiast wątpliwości, że wobec tak zarysowanej dysproporcji, przekaz ten należy traktować z przymrużeniem oka. Niemniej jednak jest on ważny z innego powodu - ukazuje jedną z funkcji kompleksów leśnych, które w tym konkretnym przypadku ułatwiły nieprzyjacielowi atak z zaskoczenia.

Ciekawą z punktu widzenia podjętych rozważań jest kolejna informacja Galla, tym razem odnosząca się do zmagań z Czechami. Otóż na mocy układu polsko-węgierskiego, w przypadku agresji cesarza na którąkolwiek ze stron paktu, sojusznik zobowiązany był do związania sił czeskich. W związku z powyższym: „skoro zatem cesarz wkroczył na Węgry, Bolesław także, dochowujący wiary, po bitwie stoczonej w środku lasów [wyróżnienie - Ł.Ć.] zwycięsko trzymał w szachu Czechy [...]"9. Dysponujemy w tym wypadku wprawdzie lakoniczną wzmianką o stoczeniu bitwy w lasach, ale - odwołując się do komentarza wydawców pierwszej polskiej kroniki - należy zaznaczyć, że chodzi tutaj o lasy sudeckie,

${ }^{6}$ Vita sancti Stanislai episcopi Cracoviensis (vita minor), wyd. S. KęTRZYŃsKI, [w:] MPH, t. IV, Lwów 1884, s. 277. Vide: J. SzymCZAK, Rycerz w hetmie, w zbroi i z tarcza, Warszawa-Bellerive-sur-Allier 2016, s. 90.

${ }^{7}$ Mistrz Wincenty zwany KadŁubkiem, Kronika polska, tłum. i oprac. B. Kürbis, Wrocław 2003 [dalej: KadŁubeK], s. 73; Magistri Vincentii dicti Kadtubek Chronica Polonorum, wyd. M. PLEZIA, [w:] MPH, s.n., t. XI, Kraków 1994 [dalej: KADŁubEK MPH], s. 54: „Multi ergo armorum pressi mole fluctibus inuoluuntur, prepauci cum rege uix enatant et licet inermes de armata hostium multitudine triumphant".

${ }^{8}$ Gall, s. 98; Gall MPH, s. 101. Vide: D. Wybranowski, Jeszcze raz o taktyce wojen pomorskich Bolesława Krzywoustego oraz okolicznościach ich finału, „Przegląd Zachodniopomorski” 2017, R. XXXII (LXI), z. 2, s. 76-77.

9 Gall, s. 114; Gall MPH, s. 116: „Quando ergo cesar Ungariam introivit, Bolezlauus quoque, fidem servans, in medio silvarum prelio comisso, victor Bohemiam prepedivit [...]”. 
odgraniczające Polskę od Czech, które stanowiły tym samym naturalną barierę, konieczną do przebycia przez potencjalnego najeźdźcę. Powyższą informację na temat walk polsko-czeskich datuje się na koniec 1108 r. $^{10}$

Trzymając się ściśle porządku chronologicznego, nie sposób pominąć interwencji Henryka V z 1109 r. w obronie wygnanego z kraju Zbigniewa Hermanowica $^{11}$. Do podjęcia tego przedsięwzięcia mieli namawiać dodatkowo Czesi, którzy

nawykli do życia z łupów i grabieży, zachęcali cesarza, by wkroczył do Polski, zapewniając go, że dobrze znają drogi i ścieżki wiodące przez polskie lasy [wyróżnienie - Ł.Ć.]. Na podstawie takich to rad i zachęt cesarz, nabrawszy nadziei, że odniesie zwycięstwo nad Polską, wkroczył [do niej] ${ }^{12}$.

Zdawał sobie zatem doskonale sprawę, że po przekroczeniu Krosna (tak zakładał pierwotny plan) będzie musiał wkroczyć w bagniste lasy, ciągnące się aż od Odry ${ }^{13}$. Warto podkreślić, że bagna otaczające wspomnianą rzekę miały kilka kilometrów szerokości, a puszcze stanowiły dodatkowy czynnik utrudniający przechodzenie przez nią ${ }^{14}$. Cesarz dotarł ostatecznie do grodu w Bytomiu, który okazał się „niemożliwy do zdobycia ze względu na obwarowania i naturalne położenie wśród opływających go wód”15. Jak podkreślił Karol Olejnik, badania archeologiczne w pełni potwierdziły opis Galla, gdyż wspomniany obiekt obronny znajdował się nad brzegiem Odry, w miejscu z natury obronnym, tj. w bagnistej dolinie, od południa zabezpieczonej przez fosę. Jedyny odcinek - przynajmniej teoretycznie umożliwiający podejście pod warownię - był broniony przez potrójną linię umocnień drewniano-ziemnych. W związku z tym napastnicy w ogóle nie byli zainteresowani szturmowaniem Bytomia, a próbowali ominąć gród. Manewr jednak nie powiódł się, a siły cesarza zostały zaatakowane przez załogę broniącą tego punktu oporu ${ }^{16}$. Istotny jest jednak fakt, że kronikarz wielokrotnie podkreślał, iż warunki naturalne dawały się we znaki napastnikom, pisząc następująco:

10 Gall, s. 114, przyp. 2 i 3.

11 Vide: S. Rosik, Bolesław Krzywousty, Wrocław 2013, s. 111 i n.; N. Delestowicz, Zbigniew. Ksiązę Polski, Poznań 2017, s. 197-210.

12 Gall, s. 130; Gall MPH, s. 131: „Insuper etiam Bohemi, vivere predis et rapinis assueti, cesarem Poloniam intrare animabant, quia se scire vias et tramites per silvas Polonie iactitabant. Cesar ergo talibus monitis et consiliis superandi Poloniam in spem ductus, ingrediens [...]”.

13 K. Olejnik, Rola środowiska geograficznego ze szczególnym uwzględnieniem terenów leśnych, $w$ walkach obronnych o zachodnia granice Polski, [w:] Puszcze i lasy w działaniach wojennych. Materiały z Ogólnopolskiej Konferencji Historyków Wojskowości poświęconej „Roli puszcz i dużych kompleksów leśnych w działaniach wojennych", zorganizowanej w Białymstoku w dniach 16-18 września 1977 r., red. Z. KosztyŁA, A. Dobroński, Białystok 1981, s. 31.

14 B. Miśkiewicz, Studia nad obrona polskiej granicy zachodniej w okresie wczesnofeudalnym, Poznań 1961, s. 30-31.

15 Gall, s. 130; Gall MPH, s. 131: „Cumque castrum Bytom municione situque nature et aquarum circuicione inexpugnabile [...]".

16 Vide: K. Olejnik, Głogów 1109, Warszawa 1999, s. 91. 
konie padały, ludzie udręczeni byli czuwaniem, trudami i głodem; a gąszcze leśne, bezdenne bagna, kłujące muchy [...] - [wszystko to] nie pozwalało na wykonanie przedsięwzięcia ${ }^{17}$.

Pozostając nadal w kręgu stosunków polsko-czeskich, nie można pominąć sprawy osadzenia na praskim tronie Borzywoja, brata ciotecznego polskiego księcia jako syna Wratysława i Świętosławy, córki Kazimierza Odnowiciela ${ }^{18}$. W relacji Galla czytamy o „bitwie stoczonej wśród lasów [wyróżnienie - Ł.Ć.] z zachodzącymi mu drogę Czechami”"19. Czynnik leśny nie stanowił w tym wypadku dla oddziałów Krzywoustego większego problemu, ponieważ „część jego wojska stała na równinach czeskich" ${ }^{20}$, a zatem przekroczyło ono granicę! Jednakże dywersja Pomorzan zmusiła nasze siły do odwrotu, a sam Borzywoj nie zdołał opanować Pragi, mimo że była ona już niemal na wyciągnięcie ręki ${ }^{21}$. Wiosną 1110 r. wojsko polskie przebywało pod Głogowem. Tymczasem siły wierne Zbigniewowi wraz z Czechami ruszyły na Polskę, ale akcja zakończyła się niepowodzeniem. $\mathrm{Ci}$, którzy uszli z życiem, szukali schronienia w lesie, określonym pejoratywnie przez Galla jako „przyjaciel zbójców” („qui silve, latronum amice”)22. Z tej gorzkiej refleksji kronikarza przebija zatem dwojaka rola kompleksów leśnych, skoro stanowiły schronienie dla przeciwnika, a o której to funkcji wspomniano już na wstępie.

Jesienią 1110 r. Bolesław Krzywousty przedsięwziął wyprawę zbrojną na Czechy w „obronie słuszności Borzywoja”. Autor pierwszej polskiej kroniki - porównując naszego księcia do Hannibala - stwierdził na początku swojego, jakże barwnego i utrzymanego w patetycznym tonie opisu, że ten, maszerując z armią na południowych sąsiadów, musiał wspinać się na rozmaite szczyty i zapuszczał się w miejsca budzące grozę, do których nikt wcześniej nie miał dostępu. Bolesław maszerował więc ze swym wojskiem przez mroczne puszcze i budował mosty na głębokich bagnach [wyróżnienie - Ł.Ć.], co miało mu zająć 3 dni i 3 noce $^{23}$. Wydaje się, że mimo naturalnych przeszkód, pochód Polaków odbył się bez żadnych dodatkowych komplikacji, gdyż Bolesław wybrał szlak dotąd

17 Gall, s. 138-139; GAll MPH, s. 140: „Equi moriebantur, viri vigillis, labore, fame cruciabantur, silve condense, paludes tenaces, musce pungentes [...] compleri propositum non sinebant”.

18 O. Balzer, Genealogia Piastów, Kraków 1895, s. 4, tabl. II, s. 107-108; K. Dróżdż, Kazimierz Odnowiciel. Polska w okresie upadku i odbudowy, Wodzisław Śląski 2009, s. 146; N. Delestowicz, Świętosława (Swatwa) - czeska królowa z dynastii piastowskiej, „Kwartalnik Prawo-Społeczeństwo-Ekonomia" 2015, t. IV, s. 16.

${ }^{19}$ Gall, s. 142; Gall MPH, s. 144: „Dum autem iter faciens in medio silvarum cum Bohemis obviantibus prelio comisso [...]".

${ }^{20}$ Gall, s. 142; Gall MPH, s. 144: „[... ] iamque pars exercitus in campis Bohemie resideret [...]”.

${ }_{21}$ A.F. Grabski, Polska sztuka wojenna w okresie wczesnofeudalnym, Oświęcim 2015, s. 199.

22 Gall, s. 143; Gall MPH, s. 145.

${ }^{23}$ Gall, s. 145; Gall MPH, s. 145-146. 
przez nikogo nieprzebyty, toteż Czesi zapewne nie spodziewali się natarcia z tej strony. Zauważmy tutaj jednak pewną sprzeczność w relacji kronikarza. Z jednej strony wspominał on o trudnych warunkach naturalnych, po czym stwierdził, że wojsko przebyło drogę w zaledwie 3 dni. W literaturze przedmiotu uznaje się za wiarygodną raczej tę drugą informację, ponieważ wojowie Sobiesława odegrali zapewne rolę przewodników, co ułatwiło marsz na Czechy ${ }^{24}$. Prawdopodobnie miejscem koncentracji wojsk był Głogów, następnie żołnierze skierowali się ku mało uczęszczanej dotąd drodze (być może właśnie dlatego Gall posłużył się stwierdzeniem o miejscach, do których nikt wcześniej nie dotarł) z Legnicy na Bolków i Kamienną Górę, Lubawkę, Žakleř i Trutnów. Wojska Krzywoustego przekroczyły granicę przed 28 września 1110 r. (dzień św. Wacława), bowiem pod tą właśnie datą Kosmas odnotował, że polskie oddziały plądrowały już Czechy ${ }^{25}$. Według relacji Galla, Bolesław po 4 dniach dotarł nad rzekę Cidlinę, natrafiając po jej prawej stronie na wojsko nieprzyjaciela. Zgodnie z jego przekazem:

gdy Polacy chcieli przeprawić się raz w górę rzeki, to znów w dole, natychmiast pojawiali się naprzeciw nich na drugim brzegu, Czesi. Była to zaś rzeka, wedle kłamliwych relacji Czechów, znajdujących się w obozie Bolesława, nader bagnista i niebezpieczna dla tak wielkiej masy wojska, nawet gdyby nikt nie stawiał oporu przeprawiającym się ${ }^{26}$.

Do starcia jednak nie doszło z powodu wycofania się Czechów. Nazajutrz Bolesław zwinął obóz i skierował się ku Łabie. Wojsko podążało wzdłuż Cidliny, tj. w kierunku zachodnim i dopiero w pobliżu Łaby przeszło na drugi brzeg wspomnianej wyżej rzeki ${ }^{27}$. Zatem w pierwotnym miejscu spotkania się wojsk polskich z siłami czeskimi musiała ona być - wbrew sugestii Galla - faktycznie trudno dostępna i dlatego Krzywousty konsekwentnie szukał miejsca umożliwiającego przejście ${ }^{28}$. Analizując dalsze losy kampanii czeskiej, należy zwrócić uwagę na interesujący z punktu widzenia zmagań armii z naturą wątek. Otóż po odprawieniu mszy św. przez biskupów, wojowie Bolesława

powoli dotarli do wejścia do lasów. Gdy zaś ogromna rzesza przyszła do lasów, nie znając tych miejsc ani nie znajdując śladu drogi, każdy sobie sam drogę torował

24 A.F. Grabski, op. cit., s. 201.

${ }^{25}$ Cosmae Pragensis Chronica Boemorum [Die Chronic der Böhmen des Cosmas von Prag], wyd. B. Bretholz, [w:] Monumenta Germaniae Historica. Scriptores rerum Germanicarum, n.s., t. II, Berlin 1955, s. 206; Kosmasa Kronika Czechów, tłum. M. Wojciechowska, wyd. 2, Wrocław 2006, s. 325 , przyp. 31 .

${ }^{26}$ Gall, s. 146; Gall MPH, s. 147: „Nam sicubi Poloni modo sursum, modo deorsum transire reputabant, ex altera parte fluminis ibi Bohemi contra stabant. Erat enim fluvius Bohemis, qui cum eo erant, mentientibus, paludosus, tante multitudini nullo resistente periculosus".

27 A.F. Grabski, op. cit., s. 202.

28 B. Miśkiewicz, op. cit., s. 28. 
przez bezdroża, wobec czego nie mógł już trzymać się znaków ani szyku [wyróżnienie - Ł.Ć.]. Doszły bowiem słuchy, że droga, którą przybyli, oraz wszystkie inne zostały zawalone [zasiekami] i dlatego wracali inną drogą, nie mogącą pomieścić takiej ilości [ludzi]. A książę Bolesław z hufcem nadwornym pozostawał z tyłu z prawego boku, puszczając całe swe wojsko przodem, jak wzorowy pasterz. Również komes Skarbimir ${ }^{29}$ z drugiego boku ukrył się bez wiedzy Bolesława w małym lasku i tam w zasadzce wyczekiwał Czechów, gdyby przypadkiem próbowali [ich] ścigać. Także hufiec gnieźnieński, poświęcony patronowi Polski, wyczekiwał wraz z niektórymi dworzanami i innymi walecznymi rycerzami na pewnej małej równinie księcia postępującego z tyłu, która to równina oddzielała większe lasy od leżącego przed nimi mniejszego lasu. Gdy zaś Bolesław podążał z boku za swym wojskiem przez ów rzadki las, na widok swoich i przez nich również dostrzeżony wziął swoich za wroga i oni podobnie uznali go za wroga; dopiero gdy bliżej podeszli ku sobie i dokładniej przyjrzeli się broni, poznali znaki polskie i w ten sposób poniechali prawie zaczętej już bratobójczej walki ${ }^{30}$.

\section{Dalej czytamy, że}

Skarbimir również z wojewodzińskim hufcem, przedzielony lasem, walczył z innymi oddziałami Czechów, tak że Bolesław nie wiedział nic zgoła o Skarbimirze, Skarbimir zaś o Bolesławie, gdzie [który] stał i czy był uwikłany w walkę ${ }^{31}$.

W tym wypadku kompleksy leśne miały duży wpływ na dezorientację polskiej armii, która nieomal stoczyła bratobójczą walkę. Podsumowując kampanię czeską, należy podkreślić, że zakończyła się ona pomyślnie dla strony polskiej. Siły czeskie zostały rozbite, a ocaleli rzucili się do ucieczki. Warto jednak zasygnalizować, iż nasze wojska zachowały sporo rozwagi, nie ruszając natychmiast

${ }^{29}$ Szerzej na temat Skarbimira vide: W. Semkowicz, Ród Awdańców w wiekach średnich, Poznań 1920, passim; J. Bieniak, Skarbimir, [w:] Polski słownik biograficzny, t. XXXVIII, Warszawa-Kraków 1997, s. 27-31.

${ }^{30}$ GALL, s. 150-151; GALL MPH, s. 150-151: „[...] paulatim ad silvarum introitum pervenerunt. Cum autem ad silvas tanta multitudo pervenisset, neque loci notitiam, neque vie vestigium habuisset, unusquisque sibi viam per devia faciebat et sic signa vel ordinem retinere iam nequiebat. Obstrusam enim viam, qua venerant, et omnes alias audiebant et ideo per viam aliam, non capacem tante multitudinis, rediebant. Dux vero Bolezlaus retro de latere dextro cum acie curiali subsistebat, totumque suum exercitum sicut pastor egregius premittebat. Comes quoque Scarbimirus ex altero latere in silva tenui Bolezlauo (nesciente) latitabat, ibique Bohemos, si forte sequerentur, in insidiis expectabat. Gneznensis etiam acies, patrono Polonie dedicate cum quibusdam palatinis aliisque militibus animosis in planicie quadam parva dominum subsistentem expectabat, que planities silvas maiores a minori silva prostante dividebat. Cumque Bolezlauus ex oblique suum exercitum per silvam tenuem sequeretur, videns suos et a suis visus, hostes reputavit suos, a suis etiam hostis similiter estimatus; sed propius (ad) invicem accedentes et arma subtilius contemplantes, signa Polonica cognoverunt et sic a pene cepto scelere desierunt".

${ }^{31}$ Gall, s. 152; Gall MPH, s. 152: „Scarbimirus quoque cum acie palatina, silvula dividente, cum aliis Bohemorum agminibus dimicabat, ita quod Bolezlauus de Scarbimiro vel Scarbimirus de Bolezlauo penitus, ubi staret, vel si prelium ageret, ignorabat". 
w pościg za uciekinierami. Obawiały się wszakże, że był to odwrót pozorowany, ponieważ „kotlina, położona w pośrodku, i las przychodziły Czechom z pomocą, zakrywając ich ucieczkę czy zasadzkę"32.

Interesujący z punktu widzenia zmagań wojska z przyrodą jest opis dotyczący wyprawy Krzywoustego na Prusy. Zasygnalizujmy w tym miejscu, że pierwszą wyprawę podjął Bolesław w latach 1107-1108. Druga natomiast datowana jest na przełom 1110/1111 r. ${ }^{33}$ Polski książę za każdym razem decydował się na atak w okresie zimy ${ }^{34}$. Odnośnie do pierwszej znanej nam wyprawy kronikarz zanotował, że:

ziemia zaś owa tak pełna jest jezior i bagien, że nawet zamkami i grodami nie mogłaby być tak ubezpieczona; toteż nie zdołał jej dotąd nikt podbić, ponieważ nikt nie mógł z wojskiem przeprawić się przez tyle jezior i bagien ${ }^{35}$.

Jeśli zawierzyć temu opisowi, nie może dziwić fakt, że to właśnie wspomniana pora roku była w tym kontekście okresem idealnym, gdyż „wkraczając do Prus, z lodu na jeziorach i bagnach korzystał [Bolesław - Ł.Ć.] jakby z mostu"36. Mimo tak trudnego - jak się wydaje - teatru wojny, Bolesław spustoszył ziemię pruską, biorąc licznych jeńców i łupy.

Na kartach kroniki Mistrza Wincentego zwanego Kadłubkiem zmagania armii z naturą nie znalazły takiego odzwierciedlenia, jak w przypadku relacji Anonima tzw. Galla, toteż tego typu przekazów jest o wiele mniej. Jakkolwiek, niewątpliwie interesujący jest wątek walk Władysława Wygnańca z braćmi. Otóż po starciu nad rzeką Pilicą $\left(1145^{37}\right)$, która „wezbrała od ich krwi” ${ }^{38}$, senior przystąpił do oblężenia Poznania (1146). Relacjonując ostatnią fazę potyczki, Kadłubek podsumował:

32 Gall, s. 153; Gall MPH, s. 153: „Convallis enim media quedam et silva Bohemos adiuvabat, que fugam eorum vel insidias occultabat". Według Galla wyprawa Bolesława na Czechy zamknęła się w 10 dniach. Jeśli jednak weźmiemy pod uwagę 28 IX oraz dzień bitwy nad rzeką Trutiną, tj. $12 \mathrm{X}$, to wówczas przedział czasu wynosi nieco więcej niż $10 \mathrm{dni}$ - vide: M. KUCHARsKi, Kalendarz wojenny w Polsce do XIV wieku (praca magisterska napisana w Katedrze Historii Polski Średniowiecznej UŁ pod kier. prof. Jana Szymczaka, Łódź 2006, maszynopis), s. 40.

33 Vide: G. BIAŁuński, Studia z dziejów plemion pruskich i jaćwieskich, Olsztyn 1999, s. 35-37; J. Powierski, Prusowie, Mazowsze i sprowadzenie Krzyżaków do Polski, t. II, Malbork 2001, s. 23; E. Kowalczyк, Dzieje granicy mazowiecko-krzyżackiej (między Drwęca a Pisa), Warszawa 2003, s. 164.

34 Vide: J. PTAK, „Jest czas wojny i czas pokoju.... W jakich porach roku prowadzono najczęściej działania wojenne w Polsce średniowiecznej?, „Acta Universitatis Lodziensis. Folia Historica” 2018, t. CII, s. 16.

${ }^{35}$ Gall, s. 109; Gall MPH, s. 112: „Terra enim illa lacubus et paludibus est adeo communita, quod non esset vel castellis vel civitatibus sic munita; unde non potuit adhuc ab aliquo subiugari, quia nullus valuit cum exercitu tot lacubus et paludibus transportari”.

${ }^{36}$ Gall, s. 154; Gall MPH, s. 154: "Illuc enim introiens, glacie lacuum et paludum pro ponte utebatur, quia nullus aditus alius in illam patriam nisi lacubus et paludibus invenitur".

37 W sprawie datacji tej bitwy vide: M. Dworsatscheк, Władysław II Wygnaniec, Kraków 2009, s. $112-114$ i przyp. 59.

${ }^{38}$ KadŁUbeK, s. 159; KadŁUbeK MPH, s. 121: „[...] cruore flumen Pilcie, iuxta quod conflictum est, ripas altius inundasse". 
kogo przypadkiem oszczędziła srogość miecza, nie oszczędził go nawał wezbranych fal; i nie mniejszą liczbę pochłonęły wezbrane fale rzeki [wyróżnienie - Ł.Ć.], niż zgładził piorunowy miecz, tak dalece, że według podania wielka liczba płazów w tej rzece udusiła się od krwi trupów ${ }^{39}$.

Nie wdając się w tym miejscu w szczegółową analizę działań zbrojnych, należy jedynie wspomnieć, że o zwycięstwie juniorów zdecydował brak dyscypliny oblegających gród i skuteczna interwencja z zewnątrz, tj. dobra współpraca między odsieczą a oblężonymi ${ }^{40}$. W świetle przytoczonego wyżej przekazu można się domyślać, że zaskoczeni przez nadciągające posiłki napastnicy, chcąc ujść z życiem, przystąpili do ucieczki. Jednakże warunki naturalne uniemożliwiły im skuteczny odwrót, co zakończyło się dla nich w konsekwencji tragicznie - poginęli w nurtach rzeki.

O walkach z Prusami nie omieszkał wspomnieć i Kadłubek. Odnotujmy w tym miejscu wyprawę Bolesława Kędzierzawego. Otóż kraina zamieszkana przez Prusów była według kronikarza

niedostępna z powodu naturalnego położenia. U samego wstępu jest matecznik zewsząd zarosły gąszczem ciernistych krzaków, gdzie pod zielenią trawy kryje się otchłań błotnej smoły. Zwiadowcy i przewodnicy wojsk zapewniają, że znaleźli niezawodną krótszą drogę przez knieje $\mathrm{e}^{41}$.

Kampania nie była pomyślna dla polskiego księcia, a rycerze ponieśli „śmierć zaplątawszy się w zarośla i krzaki cierniste [wyróżnienie - Ł.Ć.], [a] wszystkich ogarnia mrok szybko zapadającej nocy"42. Grzegorz Białuński zwrócił uwagę, że w szeregach wojsk polskich musieli znajdować się przewodnicy i zwiadowcy przekupieni przez Prusów, np. Mazowszanie (Wincenty nie określił precyzyjnie ich pochodzenia, poza użyciem sformułowania „swoi”, co nie wyklucza Polaków), którzy zapewne bardzo dobrze znali teren. To właśnie owi nieszczęśni przewodnicy mieli wprowadzić wojsko Bolesława w zasadzkę, do czego ewidentnie przyczyniły się warunki naturalne, tj. wąskie przejścia, zarośla, krzaki oraz bagna ${ }^{43}$.

${ }^{39}$ KadŁubeK, s. 161; KadŁUbeK MPH, s. 121-122: „Nam cui forsitan gladii seueritas pepercisset, inundans undarum impetus non pepercit; nec enim pauciores torrens profluentis fluctibus inuoluit, quam fulmen ensis absorbuit, adeo ut pleraque illius reptilia fluminis cruore cadauerum asserantur suffocata".

${ }^{40}$ J. Szymczak, Sposoby zdobywania i obrony grodów w Polsce w okresie rozbicia dzielnicowego, „Studia i Materiały do Historii Wojskowości” 1979, t. XXII, s. 16.

${ }^{41}$ KADŁUBEK, s. 169; KADŁUBEK MPH, s. 127: „[...] nature situ inaccessibiles. Est autem lucus in ipso transmeatus uestibulo, densetis undique consertus raspalibus, in quo limosi abyssus bituminis sub quadam graminis uerantia delitescit. Asserunt exploratores ac duces exercituum transuendi lucum, exploratissimum reperisse conpendium".

${ }^{42}$ KadŁUbeK, s. 170; KADŁUbeK MPH, s. 127: „Quidam ramalium nexibus ac uerpium intercepti obtruncantur, omnes repentine caligo noctis inuoluit”. Vide: M. Biniaś-SzKopeK, Bolesław Kędzierzawy, wyd. 2, Poznań 2014, s. 160-162.

${ }^{43}$ G. BiaŁuński, op. cit., s. 49. Przypomnijmy ponadto, że w czasie tej kampanii zginął Henryk Sandomierski - A. Teterycz-Puzio, Henryk Sandomierski (1126/1133 - 18 X 1166), Kraków 
Z kolei Kazimierz Sprawiedliwy, po pokonaniu Getów (Prusów) w 1192 r., postanowił zbrojnie rozprawić się z Połekszanami (plemię jaćwieskie) ${ }^{44}$. Byli oni „niedostępni z powodu broniących dostępu rozległych puszcz, z powodu zwartych gąszczów leśnych, z powodu smołowych bagien [wyróżnienie - Ł.Ć.]"45. Kronikarz podkreślił męstwo księcia, odnotowując, że ten przemierzył „ową nieprzebytą puszczę w ciągu trzech naturalnych dni w szybkim pochodzie" W dalszej części opisu czytamy, że Polacy

przeto nieustannie szukają sposobności do walki. Mimo długiego szukania nie znajdują jej, gdyż wszyscy nieprzyjaciele nie tyle z małodusznego strachu, ile z przemyślnej ostrożności kryli się po uroczyskach i jamach. Są bowiem bardzo wprawieni [bić się] w gęstwinie, w polu zaś [są] do niczego; więcej podstępem niż siłą [walczą] [... $]^{47}$.

Mimo pomyślnego zakończenia kampanii, nie obyło się bez przejściowych trudności, ponieważ Połekszanie złamali tymczasowy rozejm i „obaliwszy las, odcinają zupełnie odwrót [...]"48. Wspomnianą wyprawę należy datować na $1193 \mathrm{r}^{49}$

W świetle przytoczonych wyżej relacji źródłowych, odnoszących się do interesujących nas zagadnień, należy pokusić się o sformułowanie następujących spostrzeżeń i wniosków. Po pierwsze, relacje Anonima tzw. Galla górują nad przekazami Mistrza Wincentego pod względem szczegółowości opisywanych wydarzeń i zdają się prezentować więcej walorów poznawczych w zakresie prowadzenia działań zbrojnych. Po drugie, możemy wyróżnić kilka funkcji poszczególnych elementów przyrody, których znaczenie dla kampanii wojennych jest niepodważalne. Mamy tu na myśli przede wszystkim rolę kompleksów leśnych jako

2009, s. 115-121. Vide: G. BiaŁuński, Wyprawa Bolesława Kędzierzawego na Prusy w 1166 roku, „Zapiski Historyczne” 1995, z. 2-3, s. 7-20; IDEM, O dacie śmierci księcia sandomierskiego Henryka, [w:] Kaci, święci, templariusze, red. B. ŚlıwińsKi, „Studia z Dziejów Średniowiecza” 2008, nr 14, s. 23-34; M. GŁadysz, Zapomniani krzyżowcy. Polska wobec ruchu krucjatowego w XII-XIII wieku, Warszawa 2012, s. 101.

${ }^{44}$ J. Dobosz, Kazimierz II Sprawiedliwy, wyd. 2, Poznań 2014, s. 161. Szerzej na temat tej wyprawy pisze W. Caban, Polityka pótnocno-wschodnia Kazimierza Sprawiedliwego w latach 1177-1192, „Rocznik Białostocki” 1974, t. XII, s. 207-209; G. BIA£UŃski, Studia z dziejów..., s. 75-80.

${ }^{45}$ KadŁUbeK, s. 228; KADŁUbeK MPH, s. 166: „[...] propter uastissimas solitudinum intercapedines, propter concretissimas nemorum densitates, propter bituminata inaccessibilis palustria”.

${ }^{46}$ KadŁUbeK, s. 228; KadŁubeK MPH, s. 166: „Illa subinde incomeabili heremi uastitate trium naturalium dierum cursu citatissimo uix emensa [...]".

47 KADŁUbeK, s. 228; KadŁUBEK MPH, s. 116-167: „Itaque intrepidi prelium querunt, diu questium nusquam reperiunt, cunctis hostium in debris ac speluncis delitescentibus, non tam timoris pusillanimitate quam cutele industria. Sunt enim in arto exercitatissimi, set in plano nulli, plus arte quam uiribus $[\ldots]$..

${ }^{48}$ KadŁubeK, s. 228; KadŁubeK MPH, s. 167: „Pollexiani prostrato interim nemore omnem remeatum precludunt, pactioni renuntiant $[\ldots]$ ".

${ }^{49}$ G. BIAŁUŃsKi, op. cit., s. 80. 
naturalnej bariery obronnej (lasy sudeckie), możliwość ataku z zaskoczenia, jaką stwarzały gęsto porośnięte puszcze, ale z zastrzeżeniem dobrej ich znajomości lub wykorzystania wiedzy przewodników (przykład Czechów). Bywało i tak, że władcy, ufający naturalnym umocnieniom, nie obsadzali odcinków przygranicznych załogami zbrojnymi, co w konsekwencji obracało się przeciw nim. W takich przypadkach cenna i decydująca zarazem była znajomość topografii terenu przez zwiadowców, często dobrze opłaconych i przekupionych, od których zależało powodzenie przedsięwzięcia. Lasy pełniły na dodatek funkcję refugialną, a więc stwarzały oddziałom agresora możliwość szybkiego wycofania się i schronienia. Dodajmy, że ludność cywilna, porzucająca swoje dotychczasowe siedziby, także szukała naturalnego azylu ${ }^{50}$. Gęstwina leśna mogła stać się także przyczyną katastrofy, by przywołać przykład wspomnianej już pomyłki wojsk polskich i miała ponadto wpływ na dezorientację oddziałów. Inne komponenty krajobrazu naturalnego (rzeki, jeziora, bagna, pagórki, zarośla, krzaki) również pełniły dwojaką funkcję, mogły przecież przesądzić o ostatecznym zwycięstwie lub jego braku.

Kończąc niniejsze rozważania, warto przytoczyć - jakże uniwersalną z punktu widzenia podjętej problematyki - refleksję samego cesarza Fryderyka Barbarossy, który stwierdził, że

chociaż Polska sztucznie i z natury bardzo była zabezpieczona, tak iż nasi poprzednicy królowie i cesarze zaledwie $\mathrm{z}$ wielką trudnością dochodzili do rzeki Odry, my jednak dotarliśmy [...] przeszliśmy z całym naszym wojskiem rzekę Odrę, która cały ten kraj jakby murem otacza i z powodu swej głębokości uniemożliwia wszelkie przejście ${ }^{51}$.

Widać zatem wyraźnie, że Barbarossa doceniał rolę środowiska naturalnego w kontekście prowadzenia operacji wojennych, celowo jednak podkreślił niedogodności krajobrazu Polski, by w ten sposób dodać sobie splendoru. Niemniej jednak, cytat ten świadczy o tym, że każda armia - bez względu na siłę i walory bojowe, które reprezentowała - musiała stawiać czoła przeciwnościom natury, co znalazło swoje odzwierciedlenie także na kartach naszych kronik.

\footnotetext{
${ }^{50}$ J. Tyszkiewicz, op. cit., s. 69.

${ }^{51}$ Cyt. za: K. Olejnik, Rola środowiska geograficznego..., s. 32-33; Fryderyk I cesarz donosi Wibaldowi o zwycięstwie odniesionym nad Polakami we wrześniu 1157 r., [w:] MPH, t. II, Lwów 1872, s. 21: „Polonia quamvis arte et natura adomodum esset, ut antecessores nostri reges et imperatores vix magna difficultate ad fluvium Odera pervenissent [...] penetravimus, et in octava Assumptionis sanctae Mariae fluvium Oderam, qui totam terram illam quasi muro vallat, et profunditate sua omnes excludit aditus".
} 


\title{
Łukasz Ćwikła
}

\section{THE ARMY AND THEIR STRUGGLE WITH NATURE ACCORDING TO THE CHRONICLES OF ANONYM CALLED GALL AND MASTER WINCENTY CALLED KADŁUBEK}

\begin{abstract}
Summary: The components of natural environment were suitable for defending the points of resistance or surprising the enemy. However, it is important to say that without a well prepared defense they were useless. For instance the role of forests wastwofold taking into account leading the great campaigns or even smaller skirmishes. The main issue of this article is to follow the army's struggle with nature during marching and warfare (the aggression against Bohemia, Prussia and battles in the country) including its impact on both successes and defeats according to the chronicles of Anonym called Gall and Master Wincenty called Kadłubek.
\end{abstract}

Keywords: Poland, The Middle Ages, Polish medieval chronicles, history of warfare during the Middle Ages. 